diseases, in particular banana leaf spot, Mycosphaerella musicola Leach. Effective oils apparently achieve their results in a number of ways and their effects appear to be on the disease itself rather than directly on the pathogen. For this reason the author prefers "antidisease agents" to "fungicides" for use in describing them.

There are author and subject indexes for the present volume and eumulative indexes of authors and titles for Volumes 1 to 4. The present volume has maintained the standard set by its predecessors and the series remains essential reading for plant pathologists. J. H. WesteRN drugs being grouped together according to their properties where possible. The articles on individual drugs are accompanied by quotations from articles in the medical and pharmaceutical press. The second part is a list of supplementary drugs of lesser importance. There is also a list of proprietary substances usually supplied "over the counter" on request, a list of manufacturers and a classification of drugs by the disease for which they are normally used. The index is unusually comprehensive and the book should be on the bookshelf of everyone who needs a guide to modern drugs.

JOHN SPENCER

\title{
CHEMISTRY AND PHYSICS OF LIPIDS
}

\section{Chemistry and Physics of Lipids}

Edited by G. H. de Haas and five others. (Volume 1, No. 1; 1966/67.) Pp. 89. (Amsterdam: North-Holland Publishing Company, 1966.) n.p.

The new journal, Chemistry and Physics of Lipids, first appeared in November 1966. The declared editorial policy of this new journal is to publish papers in the field of molecular biology, with particular emphasis on the chemical and physical aspects of lipids. At present there is already a journal exclusively devoted to lipid research and it is by no means bursting at the seams. Moreover, Biochimica Biophysica Acta offers a whole section for papers on the biochemistry and biophysies of lipids. One wonders what prompted the editorial board and publishers of Chemistry and Physics of Lipids to launch a new journal in this field. They may have felt that a journal should be exclusively devoted to the biophysics of lipids, but surely this is carrying super-specialization too far.

It is not easy to applaud the purposes of a journal the editorial board of which sees the chemistry and physies of lipids as a cloistered enclave insulated from the hurlyburly of general biological research. If this process of super-specialization proceeds much further, the time will come when a scientist will only be able to communicate with himself, because nobody else will understand his jargon.

It would be churlish not to wish suecess to this new journal. Nevertheless, if it should fail to thrive for lack of real support, it is to be hoped that the publishers will consider whether or not to continue its publication. There are already too many specialized journals that are barely viable: to add to their number serves no useful purpose.

C. W. M. Adams

\section{THE DRUG SCENE}

\section{Extra Pharmacopoeia (Martindale)}

Incorporating Squire's Companion. Edited by R. G. Todd. Twonty-fifth edition. Pp. xxviii + 1804. (London: The Pharmaceutical Press, 1967.) $150 s$.

THE twenty-fifth edition of Martindale is obviously destined to become a vade mecum for the increasingly harassed druggist and the equally tormented prescriber. The drug scene, as the popular press keeps reminding us, is getting out of hand. No one is more aware of this than the editor of a comprehensive pharmacopoeiathe editor of this one, Mr. R. G. Todd, writes in his introduction of the "formidability" of the task that faced him after the publication of the twenty-fourth edition in 1958 . Since that time more than 1,200 drugs have been admitted to the book, and the number of new proprietary products developed over the same period is 2,400. The task of compiling a directory to all these compounds would daunt the bravest, but Mr. Todd has put together a comprehensive and ovon readable guide.

The first part of the book consists of monographs on the chief drugs of clinical and toxicological importance, the

\section{OBITUARIES}

\section{Professor H. Munro Fox}

Harold Munro Fox, who died on January 29 at the age of 77, was a zoologist of great distinction. His scientific output began with a series of ten papers, mostly on fertilization, hybridization and inheritance in sea urchins, published between 1911 and 1915. After an interlude as an officer in the Army Service Corps, London Mounted Brigade, he resumed his researches in the early twonties with a group of papers on various subjects: lunar periodicity; migration of invertebrates through the Suez Canal; animal orientation; reactions of flagellates to low oxygen tension and their use in detecting the respiratory surfaces of small invertebrates, and the chemical nature of chlorocruorin. Soon he settled down to a "main line" of work on invertebrate respiration. He was professor of zoology in the University of Birmingham during 1927 . 1941 and at Bedford College during 1941-1954, and finally professor emeritus and honorary research associate at Queen Mary College. For the wholo of this time a steady stream of important papers flowed from Fox and his pupils, on such subjects as the nature and functions of the respiratory pigments haemoglobin and chlorocruorin; the relation of metabolic rate to environmental temperature and oxygen tension; the regulation of respiratory movements; and invertebrate blood circulations. At first, these papers were mostly concerned with worms, but later he produced a series of important works on the respiration physiology and haemoglobin of crustacea, especially Daphnia. This led him on to investigate the taxonomy and general biology of freshwater crustacea, with which his latest papers are concerned.

Fox was elected to the Royal Society in 1937, and was Fullerian professor of physiology at the Royal Institution from 1953 to 1956 . He was awarded a gold medal by the Linnean Society of London in 1959, and the Darwin Medal of the Royal Society in 1966.

The whole of Fox's work is characterized by great clarity and precision, shown both in his experimental methods and in the style of his writing. His interest in the life of the animals on which he worked was unflagging. $\mathrm{H}_{\mathrm{e}}$ was an indefatigable field naturalist, and honorary president of the London Natural History Society. His friends will remember the spotlessly clear marine aquaria in his London flat, where the most delicate animals thrived and bore witness to his devotion. He was also a great European, spending his working holidays at laboratories abroad, especially in France and Italy. He served as president of the International Union of Biological Sciences from 1950 to 1953.

His enthusiasm and precision made Fox a first-class teacher, and also- together with his international outlook

fitted him for his forty years in the editorial chair of Biological Reviews, a position which he occupied from the origin of that journal in 1926 until his death. He was indeed an outstanding scientific editor, and in building up Biological Reviews he made perhaps the greatest of all his contributions to the advaneement of biology.

G. P. WenLs 